\title{
Innovation Heterogeneity in Family Firms: Evidence From the Date Industry in Saudi Arabia
}

\begin{abstract}
Researchers have argued that family firm innovation is paradoxical in nature, in that family firms often display less innovation than their nonfamily counterparts, yet they are able to be more innovative. The aim of this paper is to unpack this paradox by exploring how differences in family firms' ability (discretion and resources) and willingness (economic and noneconomic) affect their innovation activities. We adopt a qualitative, interpretive methodology based on four case studies of Saudi family firms operating in the indigenous date industry. Our findings emphasise the importance of having all four sources of ability and willingness in order for innovation to occur and how, when the new generation enters the business, the family firm's innovation posture changes to either "lagging" or "reviving". By exploring innovation in the date sector in Saudi Arabia, we contribute to the abilitywillingness paradox by distinguishing between the different sources of ability and willingness and add to an emerging narrative that acknowledges the integration of past knowledge with new innovative practices as an important and unique mechanism by which family firms can harness innovation.
\end{abstract}

Keywords: family firms, innovation heterogeneity, innovation paradox, Saudi Arabia, date industry 


\section{Introduction}

Family ownership of business organisations is ubiquitous around the world and dominant in many countries (Schulze and Gedajlovic, 2010). Although the exact numbers of the prevalence of family firms vary, researchers have consistently shown that family firms dominate global economies (Filser et al., 2016; La Porta et al., 1999; Xi et al., 2015). In Saudi Arabia, $63 \%$ of registered companies are family businesses, contributing to approximately $32 \%$ of the country's GDP (Alrubaishi and Robson, 2019). Family firms are organisations characterised by individuals related by family ties exerting substantial influence, for example, via ownership stakes or holding significant management positions (König et al., 2013). Since such firms contribute substantially as employment generators and to GDP globally, family firms can be considered an omnipresent organisational form that makes important contributions to innovation endeavours in economies worldwide (Filser et al., 2016; Xi et al., 2015).

Innovative businesses are key drivers of economic growth (Freeman, 2002). Innovation is linked to high firm performance (Brown and Eisenhardt, 1995) and considered a source of competitive advantage (Utterback and Abernathy, 1975). For the purposes of this paper, we conceptualise innovation as the set of activities through which a firm conceives, designs, manufactures, and introduces a new product, service, process, or business model (De Massis et al., 2015a). While extant innovation researchers have investigated firm-level drivers of innovation (Ahuja et al., 2008), there is a lack of understanding of the influence of family involvement on such drivers of innovation (De Massis et al., 2013; Duran et al., 2016). Unsurprisingly, research on innovation in family firms is in its infancy (Uhlaner et al., 2012), and has only recently received growing attention from both family business and innovation perspectives (Duran et al., 2016; Filser et al., 2016, 2018). 
Consequently, more research is required on this important sector of the global economy, especially as family firm innovation processes and outcomes are likely to differ from those found in other governance and ownership models due to the influence of family involvement on organisational goals (Cassia et al., 2012; Chrisman et al., 2012; WeismeierSammer et al., 2013), risk-taking (Gómez-Mejía et al., 2007; Zahra, 2005), and investment horizons (Lumpkin and Brigham, 2011). As such, understanding the role of family involvement and its effects on innovative behaviour is both of managerial and theoretical importance (Filser et al., 2016).

Researchers have suggested that innovation in family firms is paradoxical in nature, in that family firms often display less innovation than their nonfamily counterparts despite being able to be more innovative (De Massis et al., 2015a). To resolve this paradox, scholars have argued that in addition to this ability, family firms should be willing to innovate and that both ability and willingness are required conditions that determine family firms' behaviour (De Massis et al., 2014). Ability is related to discretion, stemming from family involvement in ownership, management, and governance, whereas willingness is related to the intention to pursue family-oriented goals (Chrisman et al., 2015; De Massis et al., 2014). Empirical family business innovation researchers have focused more on ability by investigating the relationship between family involvement and innovation (Arzubiaga et al., 2018; Block et al., 2013; Cucculelli et al., 2016; Matzler et al., 2015; Sciascia et al., 2015) than on willingness. Furthermore, family businesses' ability is argued to be based on both the authority to act as well as on the resources needed to achieve desired goals (De Massis et al., 2015a). The sources of family willingness, however, are a combination of both economic and noneconomic goals (Chrisman et al., 2015). As such, investigating both sources of the ability and willingness is critical to understanding innovation in family firms. 
Moreover, family businesses are not a homogenous group of organisations (Chua et al., 2012; Memili and Dibrell, 2019) with their heterogeneity originating from their governance structure, vision, and goals (Jaskiewicz and Dyer, 2017), and the context in which they operate (Wright et al., 2014); this includes the historical, temporal, institutional, spatial, and social contexts (Welter, 2011). Thus, family firms are heterogeneous in their ability and willingness to innovate (Calabro et al., 2019; Filser et al., 2018). Despite this, innovation researchers to date have primarily adopted American and Western European perspectives, suggesting a need for research from a broader geographical and cultural base to advance our understanding of innovation. Accordingly, we aim in this paper to explore how the differences in family firms' ability (discretion and resources) and willingness (economic and noneconomic) affect their innovation activities across generations in the indigenous date industry in Saudi Arabia.

Saudi Arabia is considered the world's second-largest producer of dates as well as the leader in average per capita consumption of dates (Al-Shreed et al., 2012; Alsughayir, 2013; Intezar et al., 2016). Date palm is one of the oldest fruit trees in the world, with its origins dating back to 6,000 B.C.E. (Al-Abdoulhadi et al., 2011; Al-Qarawi et al., 2003). The nutritional and functional benefits of dates as being a rich source of minerals and vitamins are well recognized (Al-Farsi and Lee, 2008). Dates also have religious significance wherein during the month of Ramadan, Muslims around the world break their fast at sunset by eating dates (Alsughayir, 2013; Intezar et al., 2016). Furthermore, the date palm tree and dates are particularly important in Saudi society, not only as a national food source, but also because of its association with customs, traditions, and social values. Around 28 million palm trees in Saudi Arabia produce more than 450 kinds of dates with an estimated annual production of a million tons of dates (Al-Shreed et al., 2012; Bushara et al., 2018). As such, the date palm is 
considered an important part of the country's economic development (Alshuaibi, 2011; Intezar et al., 2016).

Given the increasing surplus of the dates supply in the local market, there is substantial opportunity for export. However, the industry has not achieved its full potential due to quality requirements (Al-Abdoulhadi et al., 2011). Determining the quality measurement is an important factor in the productivity and profitability of the dates sector (Alsughayir, 2013). Nevertheless, aside from the fruit itself, the date palm can be used for derivative manufacturing such as date paste, jams, date syrup, and ethanol (El-Sharnouby et al., 2009; Zohri and Etnan, 2000), thus creating an opportunity for innovation in the industry.

In this paper, we make the following contributions. First, we contribute to understanding the ability-willingness paradox by distinguishing between the different sources of ability (discretion and resources) and willingness (economic and noneconomic) (Chrisman et al., 2015; De Massis et al., 2015a). In doing so, we illustrate how the absence of any of these sources can hinder innovation in family firms. Second, we provide insight into the heterogeneity of family firms (Chua et al., 2012; Jaskiewicz and Dyer, 2017) by revealing the degree of family firms' innovation based on differences in their ability and willingness and how the role of the next generation in the business changes the firm's innovation posture to be either "lagging" or "reviving". Finally, given our focus on the indigenous date industry in Saudi Arabia, we contribute to an emerging narrative that acknowledges the integration of past knowledge into innovative practices as an important and unique mechanism by which family firms can harness innovation. Although the context in which the family firms operate is habitually intertwined with social, family, and business environments (Welter, 2011; Zahra and Wright, 2011), the spatial context in which these firms operate currently remains absent from family business research in general (Wright et al., 2014) and innovation research in particular (Miller and Le Breton-Miller, 2015). This is of significance in understanding 
regional and industry-specific factors related to family firm innovativeness, given the need for wider geographical (e.g., non-Western) and sectoral research in the field (Calabro et al., 2019; Filser et al., 2016).

This paper is structured as follows. We commence by outlining the key constructs of our theoretical framing, namely, the family firm innovation paradox and the role of innovation through tradition. Next, we outline our research design by detailing the empirical context, methodology, and data collection and analysis. This is followed by a critical evaluation of four family firm case studies in the date industry. Finally, we consider the implications of our arguments to advance the theoretical and practical understanding of family firm innovation in emerging economies.

\section{Literature Review}

Innovation and Entrepreneurship in Family Firms

In contributing to both profitability and growth, entrepreneurship is considered a key factor in driving economic prosperity, job creation, and wealth generation (Hitt et al., 2001). Entrepreneurship enhances the performance of companies and therefore their growth in a variety of contexts, including developing countries (Naudé, 2010), minority businesses (Bates et al., 2007), rural businesses (De Rosa et al., 2019), farming (McElwee, 2006), and family firms (Uhlaner et al., 2011). Family business researchers recognise entrepreneurship as playing a significant role in the survival of these kinds of organisations (Jaskiewicz et al., 2015). Indeed, the term 'family entrepreneurship' refers to those family firms that consistently engage in entrepreneurial activities including innovation, new venturing, and/or strategic renewal across multiple generations (Cruz and Nordqvist, 2012).

Since Schumpeter's seminal work in 1934, researchers have recognised the importance of innovation in organisations' survival (Wiklund and Shepherd, 2005), competitive advantage (D’Aveni et al., 2013; Utterback and Abernathy, 1975), and financial 
performance (Brown and Eisenhardt, 1995; Calantone et al., 2002). Innovation is the process through which new products, services, processes, and business models are introduced (Drucker, 1985). Innovation can take many forms such as research and development (R\&D), technological advancement, patents, new product development (NPD), manufacturing processes, advances in marketing, and organisational structuring (Diaz-Moriana et al., 2018). In this era of environmental uncertainty and complexity (Chen et al., 2019), managers of all firms, family or nonfamily, need to implement innovative strategies to steer their organisations towards sustainability and longevity (Kraiczy, 2013). However, researchers creating models that predict the success and failure of innovation in organisations have long neglected the effect of family involvement in firms (Urbinati et al., 2017), thus leading to recent interest among scholars to explore the determinants of innovation in family firms (Calabro et al., 2019; Cassia et al., 2012; Chrisman et al., 2015; De Massis et al., 2014, 2015a; Filser et al., 2018; Rondi et al., 2018).

The development of family business as a field of research is characterised by two streams of research: the differences between family and nonfamily businesses and those within various family businesses (Xi et al., 2015). Similarly, the literature on innovation in family firms is fragmented with inconsistent findings (Filser et al., 2018, 2016). Initially, various researchers empirically investigated differences in innovation between family and nonfamily firms and emerged with contradicting findings (Duran et al., 2016). For example, Chrisman and Patel (2012) and Block et al. (2013) found that family ownership had a negative relationship with $R \& D$ intensity. They explained this finding using a socioemotional wealth (SEW) perspective as their theoretical framework, arguing that family firms invested less in R\&D to protect family control. However, drawing upon the resource-based view (RBV), Llach and Nordqvist (2010) found that family firms were more innovative than nonfamily firms, arguing that the unique resources of family firms such as human, social and 
marketing capital provided family firms with a competitive advantage over their nonfamily counterparts. Moreover, Matzler et al. (2015) found that while family firms invested less in innovation input such as $R \& D$, they exhibited higher innovation output. Indeed, family firms were found to be more efficient in transforming innovation inputs into innovation outputs (Duran et al., 2016). To investigate these differences further, De Massis et al. (2015b) used the RBV along with agency, stewardship, and behavioural and other theories to show that family firms differed from nonfamily firms with regard to strategies of product innovation and organisation of the innovation process. Indeed, scholars agree that when it comes to innovation, there are differences between family and nonfamily firms (Cassia et al., 2012; De Massis et al., 2015b; Duran et al., 2016; Matzler et al., 2015).

Given the idiosyncratic nature of family firms in relation to their nonfamily counterparts (Cassia et al., 2012; Chrisman et al., 2012), researchers have now begun to conduct studies that explore the sources of innovation within family firms. Ability and willingness to innovate are the two main drivers that cause differential behaviour in family and nonfamily firms (Calabro et al., 2019; Chrisman et al., 2015; De Massis et al., 2014, 2015a; Rondi et al., 2018). "Ability” is defined by family involvement in ownership, management, and governance that enables them to manage and allocate the firm's resources, while willingness is the motivation to pursue family-related goals (De Massis et al., 2014). Put differently, ability is the "discretion to act" while willingness is the "disposition to act" (Chrisman et al., 2015, p. 310). Since there is considerable commitment in terms of resources and time involved in innovation, family firms have prove their ability to innovate by having long-term control over the firm (Diaz-Moriana et al., 2018; Miller and Le Breton-Miller, 2005). Roessl et al. (2010) also stated that family firms were more responsive in innovation decision-making due to the presence of less bureaucracy and being less hierarchical, but that this responsiveness appears to be limited to short-term rather than long-term decision making. 
On the other hand, scholars have argued that family firms' willingness was low as they were often characterised as conservative, traditional and risk-averse (Block et al., 2013; Sciascia et al., 2015) due to their SEW endowment, i.e., the affective value that a family derives from the firm influencing their decisions (Gomez-Mejia et al., 2007). Roessl et al. (2010) also argued that family firms' risk aversion, nepotism, resistance to change and internal conflicts as well as reluctance to hand control over to skilled managers who are not family made family businesses less able to innovate. As such, ability and willingness can cause a paradoxical tension as family firms known to have superior innovation abilities may lack the willingness to use them (Chrisman et al., 2015; McAdam et al., in press). Yet, both ability and willingness are necessary conditions that enable family firms to innovate; the absence of either is detrimental (De Massis et al., 2014). Moreover, to unlock the ability-willingness paradox, De Massis et al. (2015a) argued that ability has a resource component in addition to a discretion component. With regard to willingness, family business scholars investigating innovation have widely relied on the noneconomic goals of family firms in terms of SEW endowment (Hauck and Prügl, 2015; Miller et al., 2015; Sciascia et al., 2015). However, family businesses are concerned with both financial and nonfinancial goals, both of which were crucial to their willingness (Chrisman et al., 2015).

Moreover, family firms are known for their long-term orientation (Diaz-Moriana et al., 2018; Lumpkin and Brigham, 2011), with their business operations typically spanning across generations. Researchers to date have examined the variation across generations in terms of succession (Sharma et al., 2003; Weismeier-Sammer and Hatak, 2014), retained earnings (Vandemaele and Vancauteren, 2015), entrepreneurial orientation (Cruz and Nordqvist, 2012) and transgenerational entrepreneurship (Jaskiewicz et al., 2015). With regard to innovation, the evidence is inconclusive. While some researchers found that the involvement of the next generation is detrimental to innovation in family firms (Block et al., 
2013; Bloom and Van Reenen, 2007), others have maintained that these generations enhanced innovation (Carvalho and Williams 2014; Cruz and Nordqvist, 2012; Hillebrand, 2019). These conflicting findings may be attributed to the heterogeneity of innovation in family firms (Filser et al., 2018).

An important gap in current family business innovation research is the assumption of homogeneity within family firms and as a consequence, their innovation activities (Calabro et al., 2019). To advance family business research, scholars have attempted to understand the differences within family firms themselves (Chua et al., 2012). Whilst researchers initially explored the heterogeneity of family firms in terms of family involvement in ownership and management (Fiegener, 2010) and the context in which the family firm operates (Wright et al., 2014), they have paid little attention to innovation, thus leading to the need to consider the heterogeneity of family firms when investigating their innovation activities (De Massis et al., 2014). This heterogeneity can stem from the differences in ability and willingness as well as from the generation managing the business (Calabro et al., 2019). In this paper, we respond to this need by exploring how the heterogeneity of family firms' ability (discretion and resources) and willingness (economic and noneconomic goals) affect their innovation activities across generations in the date industry.

\section{Innovation through Tradition}

Formerly, researchers assumed family firms were conservative and anchored to past practices (Roessl et al., 2010), however, they have argued that these firms' innovative behaviour changes over time, particularly when the next generation takes over leadership of the family firm (Suess-Reyes and Fuetsch, 2016). Moreover, an emerging narrative that acknowledges that the integration of past knowledge into new practices is an important and unique mechanism by which family firms can harness innovation (De Massis et al., 2016; Erdogan et al., 2019; Rondi et al., 2018). The premise of this narrative is based on family firms' 
longevity (Miller and Le Breton-Miller, 2005) and long-term orientation (Lumpkin and Brigham, 2011). Such temporality creates a competitive advantage in innovation for family firms (Le Breton-Miller and Miller, 2011). Nevertheless, family firms face a contradiction between the necessity of adhering to traditional practices for preserving their identity and the pull towards the adaptation of new practices (Erdogan et al., 2019).

Combining insights from prior research and findings of their own study, De Massis et al. (2016) presented a new strategy called innovation through tradition, whereby the authors categorised the sources of past knowledge into two domains, firm tradition, and territorial tradition. They argued that long-lasting family businesses do not adhere rigidly to their traditions but rather recognise those traditions as an opportunity to discover and amalgamate new knowledge, thereby translating it into innovation. Working along the same lines, Erdogan et al. (2019) coined a new term, trad-innovation, and asserted that family firms must reconcile past traditions with innovative knowledge to succeed. Knowledge from territorial traditions can therefore be used to reinterpret product functionalities and/or enable product meanings.

\section{Methodology}

\section{Method}

The methodology adopted was qualitative and interpretive in nature, involving a case studybased data collection method for four Saudi family firms operating in the date industry. Even though the family business innovation field is dominated by quantitative research, researchers have called for qualitative research to provide a more nuanced understanding of innovation in this type particular type of organisation (Filser et al., 2016). Scholars, in particular those studying family firms (Cassia et al., 2012; De Massis and Kotlar, 2014), have acknowledged the suitability of case studies in ascertaining relevance and understanding of unexplored phenomena (Lettl et al., 2006). For example, Hall et al. (2001) have suggested that case studies represent a legitimate and interpretative approach to fieldwork and analysis for 
exploratory research into family firms. Moreover, De Massis and Kotlar (2014) also supported using case study methods in family business research, describing them as a "powerful methodology that can be used in a rigorous, creative and wide-ranging variety of ways to advance family business research" (p. 15-16).

Our sampling is purposive in nature, in which we selected four multigenerational family firms. The sample consists of family firms in the Saudi Arabian date palm industry, following recent calls for sectoral studies in family business innovation research (Calabro et al., 2019; De Massis and Foss, 2018). Although there is no optimum number of cases in multiple case study design, Eisenhardt (1989) endorses 4-10 cases, as fewer than four would sustain difficulties in formulating complex theories, whilst greater than 10 would suffer from superfluity or convolution of data. Consequently, we deemed that four cases were appropriate for the current study to observe replication logic and, in particular, to pursue distinctive patterns of theoretical replications (Yin, 2015). Our unit of analysis is the family firm and, building upon a previously operationalised definition of the family firm (Kellermanns et al., 2012), we defined our sample by the following criteria. First, a single family must control and influence the firm and at least two family members must be actively involved in managing the business. Second, the family must aspire to pass the business to the next generation, which reflects their succession intentions and therefore their long-term orientation.

We conducted semi-structured case interviews, follow-up interviews and observations (plant/office tour, family visits) and supplemented them with archival data from various sources including industry reports, government documents, company website, and news articles. We began interviews with background questions about the participants, their family, and the firm and then moved to questions about innovation, governance, resources and goals (See Table 1 for the interview schedule). We conducted interviews in Arabic with two family 
members from the top management team of each firm. After obtaining participant permission, we digitally recorded the interviews, after which, a member of our research team transcribed them and a professional translator translated them. The average duration of interviews was 61 minutes, with the longest interview lasting nearly two hours. We provide an overview of the four family firm cases in Table 2 .

[INSERT TABLE 1 ABOUT HERE]

[INSERT TABLE 2 ABOUT HERE]

\section{Data Analysis}

We followed four stages in the data analysis, which was facilitated by the NVivo 12 qualitative data analysis software (Richards and Richards, 1994). First, we read the transcripts to immerse ourselves in the data. Then we assigned codes to the text by looking for patterns and themes within and across cases. During this first-order coding process, we used existing frameworks while remaining open to newly emerging themes. Next, we grouped codes together to create higher-order themes. For instance, codes related to "financial resources", "human resources", and "know how" were grouped to form "ability as resources". During the last stage, we iteratively analysed the data by moving between the transcripts and prior literature until we obtained a satisfactory set of themes that reflected the data. We obtained two major theoretical themes from this process (i.e. innovation posture and innovation through tradition), which enabled us to answer our research aim. We shared and discussed the themes with the research team throughout the analysis process to ensure the soundness and inter-reliability of our analyses. Finally, the themes were contrasted within and between cases resulting in further categorisation of the themes based on the firm being in the founder or next-generation phase. In Table 3, we illustrate the data structure for first- 
order codes, higher-order themes and theoretical themes upon which we have organised the presentation of our findings.

\section{[INSERT TABLE 3 ABOUT HERE]}

\section{Findings and Discussion}

We now present and discuss our findings, which are explored in detail and illustrated with selected portions of participant narrations or "power quotes" (Pratt, 2009). In addition, we outline associated proof quotes (Pratt, 2009) in Appendix 1.

\section{Innovation Posture}

In our cross-case analysis, we found that the presence of all four sources of innovation (ability as discretion and resources and economic and noneconomic willingness) as necessary for innovation to occur, and that the absence of any one of these four conditions would hinder innovation in family firms. Moreover, when the new generation enters the business, the innovation posture in the family firm changes to either "lagging" or "reviving". In two of the cases, namely Barhi and Sultana, we found the firms to be lagging in innovation from the founder phase. In the two other cases, Sukkari and Khalas, we found the next-generation family members to be reviving the founder's business by engaging in innovative activities. Table 4 presents the findings from our four case studies and their respective innovation postures.

\section{[INSERT TABLE 4 ABOUT HERE]}

When the next generation enters the business, the differences in the possible changes in the firm's innovation posture not only indicate the heterogeneity of family firms based on 
their ability and willingness, but also the heterogeneity based on the generation managing the business (Calabro et al., 2019). This is of significance as previous researchers published contradictory findings in regard to innovation in family firms across generations (Cruz and Nordqvist, 2012; Block et al., 2013). Our findings showed that such contradictory results may be due to overlooking the ability and willingness conditions of innovation in family firms.

\section{Lagging in Innovation}

Barhi and Sultana were innovative in the founder phase, with their innovation activities stemming from their founder's vision and being pioneers in the industry. As Barhi-2 stated, "During the time of the factory's initiation, the first in our region, the machines were from Germany and Switzerland, ... chocolate machines, my father transformed them to become dates machines. My dad built something that was unique back then!" While Sultana-1 (the founder) explained, "We got the idea of pressing the dates because people from Nejd region liked the pressed dates at that time ... and the pressed dates at that time were bad and the quality was poor. ... the machine that we imported from Germany, was a unique machine, . . . no one was in the market at that time".

Such innovation in the founder phase reflects what Kellermanns et al. (2012) refer to as the "founder effect" (p. 90) whereby family firms' founders are essentially entrepreneurs (Salvato, 2004). Yet, researchers have argued that this innovation diminishes over time with increased generational involvement (Block et al., 2013). Indeed, we found that when the next generation entered the business, they failed to maintain previous levels of innovation, with innovation failure due to the absence of one or more of the ability and willingness components (De Massis et al., 2014). As Barhi-1 explained, "I wanted to develop the business and make it more innovative, but that didn't work because I was shocked by the reality, I wanted to get into other industries like medical alcohol and sugar but these kinds of ventures require big investment!” However, Barhi-2 declared, "Before we were more 
innovative, now honestly aren't. We are at the same level of others". Archival data, especially certificates of excellence and achievements that referred specifically to the founder phase, supported these statements. Additionally, the next generation appeared to show little interest in the business (Hauck and Prügl, 2015), which indicates a lower willingness. As explained by Sultana-1, "one of our farms is more than $50 \mathrm{~km}^{2}$, it contains 4500 palms and produces delicious dates! But I sold the farm because my sons didn't have any interest in the business". This was confirmed by the son, Sultana-2, who stated, "In our case, it's difficult to innovate!" The research team also conducted observational factory site visits and discovered that the machinery currently used was implemented during the founder phase without any upgrade or modifications.

The Barhi case exhibited the lack of ability as discretion, an important condition for innovation to occur (De Massis et al., 2014), and an example of where the decision-making process differed during the next generation phase (Mitchell et al., 2009). Barhi-1 remarked, "When the owner is one person he usually sets policies and so on. When we transitioned to become a company owned by multiples, we faced real problems". Barhi-2 stated, "It's a partnership company and has things that if you were the owner you might go ahead and do, but you need consensus, you need voting in". In Sultana's case, the low willingness to innovate was due to limited economic incentive, another source of willingness (Chrisman et al., 2015). Sultana-1 stated, "Nowadays, we have more than 30 date factories so competition has increased and the prices changed because the products are everywhere, so we have huge production of dates which negatively impacts the scale of income ranking". Such limited financial incentives resulted in the firm focusing more on the profitable businesses within their portfolio, which the research team observed during firm site visits as well as on firm websites.

Reviving Innovation 
Though our cross-case comparison, we found that the Sukkari and Khalas cases showed no innovative activities during the founder phase. For example, talking about his father's leadership, Sukkari-1 explained, “My father didn’t have a vision. he wasn’t thinking about kinds of dates ... specifying a type and working on marketing it. He would plant anything! He was then shocked to have 200,000 palm trees of which only $20 \%$ were useful, and this was wrong!" While the founder of Khalas tried establishing an innovative date business, they failed due to lack of willingness and a unified vision; they stated, "We tried, our ambition was really high ... would believe we would benefit from dates, palm trees and palm trees wastes, we established a company, but it failed. Some of our family didn't like what was going on, they didn't believe in it". However, the next generation revived innovation activities when they entered the business. In contrast to the Barhi and Sultana cases, these family films cases is supported by the narrative that the next generation boost innovation in family firms (Carvalho and Williams 2014; Hillebrand, 2019). In the case of Sukkari, the next generation capitalised on their ability and willingness after the founder's departure to create an international brand of date-related products. As Sukkari-1 stated, "So our brand started seven or eight years ago, and we got it registered in Saudi Arabia and other countries. ... the innovation is our determination in the brand, to specialise in the supply chain, to deliver dates from farms to shelves". We triangulated the next generation's innovation activities in laboratories and branding by talking to employees, reading news articles and reviewing the firm's website.

Moreover, Khalas revived their innovation after gaining willingness by reestablishing the firm with close family members and introducing innovative derivatives from palm trees such as biofuel and wood. Khalas-1 stated, "We came up with a very good induce that we can benefit from in a way that we create organic fertilisers, in the sense that we first create clean biofuel because we have methane. At the same time, we can use the rest to 
fertilise palm trees". Their family firm also produced date-based nutritional products such as date spread, powder and jam. Khalas proclaimed, "There is great potential for dates instead of our children eating Nutella containing large amounts of fats and white sugar! Through our project, we will produce dates similar to Nutella spreadable, so you can make sandwiches for kids and all”.

\section{Innovation Through Tradition}

We confirmed dates to be part of Saudi culture and tradition across all cases. For example, in family home visits, the research team was offered Arabic coffee and varieties of dates as a sign of hospitality. As Barhi-1 remarked, "Dates are part of our daily lives, our product is an everyday food in our culture and heritage.... dates are integrated in our culture. When someone visits you, you give them dates, and naturally they will talk about the dates: What type of date is it? How did you sort them out? So even the sorting process is an interesting topic in our culture". Dates are deeply embedded in Saudi Arabian society (Alsughayir, 2013) and considered a national food source, as Sultana-1 noted, "I was born in a dates farm! But it is not us only, people of Njad survived starvation by eating dates, some people didn't have anything except those dates and water". While Barhi-2 affirmed, "It goes without saying that dates are a national wealth, meaning that it is a must!" Khalas-2 exclaimed, "This is a national product, no one in the world has what we have!".

The integration of past knowledge, contextually embedded within the region and seen as a form of leverage for innovation practices (De Massis et al., 2016), was an important driver with regard to economic development of the country (Alshuaibi, 2011). As Khalas-1 explained, "I'm one of the '70s students who went to the USA as an undergraduate and corn really caught my attention in the States, so, I started wondering how people all around the world make the best out of their fruits, you find juices, powder, you find syrup, you find creams, I mean they transform them into many products of added-value! In fact, innovation 
in the date industry was considered an opportunity in the country still not fully realised in terms of its innovation potential.Sukkari-1 explained, "Our advantage is that the Arabian Peninsula is the essence, Makkah and Al-Medina have their impact on 2.2 billion Muslims! Even if you say I'll market the product in Makkah and Al-Median, this has an added value, it has an added value compared to any other place in the world. So, the base to us is very strong and I think when it's well-used, it's very important! So that's why I'm telling you we didn't do it justice!" Barhi-1 also noted the advantage of the importance of dates for Muslims (Intezar et al., 2016) and commented, "I always think of it this way, Earth has maybe 1 billion Muslims, so in Ramadan, what if each one of them eats one! This is how I think of it when I go to buy dates now because there will always be demand no matter what!" Thus, integrating this tradition into new innovative practices is an effective means by which family firms in the region can boost their innovativeness (De Massis et al., 2016; Erdogan et al., 2019; Rondi et al., 2018).

\section{Conclusion and Implications}

In this paper, we aimed to explore how the differences in family firms' ability (discretion and resources) and willingness (economic and noneconomic) affected their innovation activities across generations. To achieve this, we focused on the date industry in Saudi Arabia, thus responding to the need for sectorial studies in family business innovation research. This focus enabled us to contribute to an emerging narrative that acknowledges the integration of past knowledge into new practices as an important and unique mechanism by which family firms can harness innovation (De Massis et al., 2016; Erdogan et al., 2019). Additionally, we highlight that in the case of family firms, it is critical to have both ability (discretion and resources) and willingness (economic and noneconomic) for innovation to occur. Moreover, we observed firms' heterogeneity in this ability and willingness with respect to how, when the new generation enters the business, the family firm's innovation posture changes to be 
either "lagging" or "reviving". We also contributed to research that acknowledges the integration of past knowledge into new innovative practices as an important and unique mechanism by which family firms can harness innovation. We also responded to the need for family firm research conducted in a non-American/Western context, which is currently lacking in family business research in general (Wright et al., 2014) and innovation research in particular (Miller and Le Breton-Miller, 2014).

Additionally, our findings have important policy implications. Family business leaders should be encouraged to exercise discretion when it comes to innovation, particularly with respect to decision-making and resource allocation. This is particularly relevant in the Saudi Arabian context, where innovation and entrepreneurship are considered main drivers in the diversification of the Saudi economy away from the dependence on the oil industry (Miniaoui and Schiliro, 2016), as the government articulated in its economic reform plan, Vision 2030. Thus, the nurturing and development of entrepreneurship and innovation is considered pivotal in the Kingdom's future.

Of course, our study is not without limitations that provide pathways for future research. The study is exploratory in nature because our aim was to gain an understanding of family business innovation in the date industry in Saudi Arabia. Thus, our findings cannot be generalised to other populations or sectors. Nevertheless, we hope this study will motivate family business researchers to examine whether our findings can be statistically tested, especially in relation to the importance of the presence of all four sources of innovation that enable family firms to engage in innovation activities. Moreover, given the temporality of family firms, we recommend a longitudinal study across multiple generations as a fruitful path of research in family business innovation. 


\section{References}

Ahuja, G., Lampert, C.M. and Tandon, V. (2008) Moving beyond Schumpeter: management research on the determinants of technological innovation. Academy of Management annals 2(1): 1-98.

Al-Abdoulhadi, I.A., Al-Ali, S., Khurshid, K., Al-Shryda, F., Al-Jabr, A.M. and Abdallah, A.B. (2011) Assessing fruit characteristics to standardize quality norms in date cultivars of Saudi Arabia. Indian Journal of Science and Technology 4(10): 1262-1266.

Al-Farsi, M. A., and Lee, C. Y. (2008) Nutritional and functional properties of dates: a review. Critical reviews in food science and nutrition 48(10): 877-887.

Al-Qarawi, A.A., Ali, B.H., Al-Mougy, S.A. and Mousa, H.M. (2003) Gastrointestinal transit in mice treated with various extracts of date (Phoenix dactylifera L.). Food and Chemical Toxicology 41(1): 37-39.

Al-Shreed, F., Al-Jamal, M., Al-Abbad, A., Al-Elaiw, Z., Abdallah, A.B. and Belaifa, H. (2012) A study on the export of Saudi Arabian dates in the global markets. Journal of Development and Agricultural Economics 4(9): 268-274.

Alrubaishi, D. and Robson, P. (2019) Innovation in Saudi Family SMEs: The Role of Social Capital and Family Involvement. International Review of Entrepreneurship 17(1).

Alshuaibi, A. (2011) The econometrics of investment in date production in Saudi Arabia. Int. J. Appl. Econ. Finance 5: 177-184.

Alsughayir, A. (2013) The impact of quality practices on productivity and profitability in the Saudi Arabian dried date industry. American Journal of Business and Management 2(4): 340-346.

Arzubiaga, U., Kotlar, J., De Massis, A., Maseda, A. and Iturralde, T. (2018) Entrepreneurial orientation and innovation in family SMEs: Unveiling the (actual) impact of the Board of Directors. Journal of Business Venturing 33(4): 455-469.

Bates, T., Jackson III, W. E., and Johnson Jr, J. H. (2007) Advancing research on minority entrepreneurship. The Annals of the American Academy of Political and Social Science 613(1): 10-17.

Block, J., Miller, D., Jaskiewicz, P. and Spiegel, F. (2013) Economic and technological importance of innovations in large family and founder firms: An analysis of patent data. Family Business Review 26(2): 180-199.

Bloom, N., and Van Reenen, J. (2007) Measuring and explaining management practices across firms and countries. The quarterly journal of Economics 122(4): 1351-1408.

Brown, S.L. and Eisenhardt, K.M., (1995) Product development: Past research, present findings, and future directions. Academy of Management Review 20(2): 343-378.

Bushara, M.H., Alkoaik, F., Abasaeed, A. and Fulleros, R. (2018) Lactic acid production from wasted dates in Saudi Arabia using Single Culture Lactobacillus casei ATCC 393 and Lactobacillus acidophilus and mixed culture. Advances in Bioresearch 9(2).

Calabro, A., Vecchiarini, M., Gast, J., Campopiano, G., De Massis, A. and Kraus, S. (2019) Innovation in family firms: a systematic literature review and guidance for future research. International Journal of Management Reviews 21(3): 317-355.

Calantone, R.J., Cavusgil, S.T. and Zhao, Y. (2002) Learning orientation, firm innovation capability, and firm performance. Industrial Marketing Management 31(6): 515-524. 
Carvalho, L., and Williams, B. (2014) Let the cork fly: creativity and innovation in a family business. The International Journal of Entrepreneurship and Innovation 15(2): 127133.

Cassia, L., De Massis, A., and Pizzurno, E. (2012) Strategic innovation and new product development in family firms: An empirically grounded theoretical framework. International Journal of Entrepreneurial Behavior \& Research 18(2): 198232.

Chen, J. X., Sharma, P., Zhan, W., and Liu, L. (2019) Demystifying the impact of CEO transformational leadership on firm performance: Interactive roles of exploratory innovation and environmental uncertainty. Journal of Business Research 96: 85-96.

Chrisman, J. J., Chua, J. H., and Sharma, P. (2005) Trends and directions in the development of a strategic management theory of the family firm. Entrepreneurship Theory and Practice 29(5): 555-576.

Chrisman, J.J. and Patel, P.C. (2012) Variations in R\&D investments of family and nonfamily firms: Behavioral agency and myopic loss aversion perspectives. Academy of Management Journal 55(4): 976-997.

Chrisman, J.J., Chua, J.H., Pearson, A.W. and Barnett, T. (2012) Family involvement, family influence, and family-centered non-economic goals in small firms. Entrepreneurship Theory and Practice 36(2): 267-293.

Chrisman, J.J., Chua, J.H., De Massis, A., Frattini, F. and Wright, M. (2015) The ability and willingness paradox in family firm innovation. Journal of Product Innovation Management 32(3): 310-318.

Chua, J.H., Chrisman, J.J., Steier, L.P. and Rau, S.B. (2012) Sources of Heterogeneity in Family Firms: An Introduction. Entrepreneurship Theory and Practice 36(6): 11031113.

Cruz, C., and Nordqvist, M. (2012) Entrepreneurial orientation in family firms: A generational perspective. Small Business Economics 38(1): 33-49.

Cucculelli, M., Le Breton-Miller, I. and Miller, D. (2016) Product innovation, firm renewal and family governance. Journal of Family Business Strategy 7(2): 90-104.

D'Aveni, R.A., Dagnino, G.B. and Smith, K.G. (2010) The age of temporary advantage. Strategic Management Journal 31(13): 1371-1385.

De Massis, A., Frattini, F. and Lichtenthaler, U. (2013) Research on technological innovation in family firms: Present debates and future directions. Family Business Review 26(1): 10-31.

De Massis, A. and Kotlar, J. (2014) The case study method in family business research: Guidelines for qualitative scholarship. Journal of Family Business Strategy 5(1): 1529.

De Massis, A., Kotlar, J., Chua, J.H. and Chrisman, J.J. (2014) Ability and willingness as sufficiency conditions for family-oriented particularistic behavior: implications for theory and empirical studies. Journal of Small Business Management 52(2): 344-364.

De Massis, A., Di Minin, A. and Frattini, F. (2015a) Family-driven innovation: Resolving the paradox in family firms. California Management Review 58(1): 5-19. 
De Massis, A., Frattini, F., Pizzurno, E. and Cassia, L. (2015b) Product innovation in family versus nonfamily firms: An exploratory analysis. Journal of Small Business Management 53(1): 1-36.

De Massis, A., Frattini, F., Kotlar, J., Petruzzelli, A.M. and Wright, M. (2016) Innovation through tradition: Lessons from innovative family businesses and directions for future research. Academy of Management Perspectives 30(1): 93-116.

De Massis, A. and Foss, N.J. (2018) Advancing Family Business Research: The Promise of Microfoundations. Family Business Review 31(4): 386-396.

De Rosa, M., McElwee, G., and Smith, R. (2019) Farm diversification strategies in response to rural policy: A case from rural Italy. Land use policy 81: 291-301.

Diaz-Moriana, V., Clinton, E., Kammerlander, N., Lumpkin, G.T. and Craig, J.B. (2018) Innovation motives in family firms: A transgenerational view. Entrepreneurship Theory and Practice, p.1042258718803051.

Drucker, P. (1985) Innovation and Entrepreneurship: Practice and Principles. New York: Harper \& Row.

Duran, P., Kammerlander, N., Van Essen, M. and Zellweger, T. (2016) Doing more with less: Innovation input and output in family firms. Academy of Management Journal 59(4): 1224-1264.

Eisenhardt, K.M., (1989) Building theories from case study research. Academy of Management Review 14(4): 532-550.

El-Sharnouby, G.A. and Al-Eid, S.M. (2009) Utilization of enzymes in the production of liquid sugar from dates. African Journal of Biochemistry Research 3(3): 041-047.

Erdogan, I., Rondi, E. and De Massis, A. (2019) Managing the tradition and innovation paradox in family firms: A family imprinting perspective. Entrepreneurship Theory and Practice, p.1042258719839712.

Fiegener, M.K. (2010) Locus of ownership and family involvement in small private firms. Journal of Management Studies 47(2): 296-321.

Filser, M., Brem, A., Gast, J., Kraus, S., and Calabrò, A. (2016). Innovation in Family FirmsExamining The Inventory And Mapping The Path. International Journal of Innovation Management 20(06): 1650054.

Filser, M., De Massis, A., Gast, J., Kraus, S., \& Niemand, T. (2018). Tracing the roots of innovativeness in family SMEs: The effect of family functionality and socioemotional wealth. Journal of Product Innovation Management 35(4): 609-628.

Freeman, C. (2002) Continental, national and sub-national innovation systemscomplementarity and economic growth. Research Policy 31(2): 191-211.

Gómez-Mejía, L.R., Haynes, K.T., Núñez-Nickel, M., Jacobson, K.J. and Moyano-Fuentes, J. (2007) Socioemotional wealth and business risks in family-controlled firms: Evidence from Spanish olive oil mills. Administrative Science Quarterly 52(1): 106-137.

Hall, A., Melin, L. and Nordqvist, M. (2001) Entrepreneurship as radical change in the family business: Exploring the role of cultural patterns. Family Business Review 14(3): 193208. 
Hauck, J. and Prügl, R. (2015) Innovation activities during intra-family leadership succession in family firms: An empirical study from a socioemotional wealth perspective. Journal of Family Business Strategy 6(2): 104-118.

Hillebrand, S. (2019) Innovation in family firms-a generational perspective. Journal of Family Business Management 9(2): 126-148.

Hitt, M. A., Ireland, R. D., Camp, S. M., and Sexton, D. L. (2001) Strategic entrepreneurship: Entrepreneurial strategies for wealth creation. Strategic management journal 22(6-7): 479-491.

Intezar, M., Abdallah, A., and Rao, V. (2016) Opportunities and Challenges of Dates Industry in Saudi Arabia: A Study of AlKharj Region. Journal of Applied Economic Sciences 11(3): 41.

Jaskiewicz, P., Combs, J. G., and Rau, S. B. (2015) Entrepreneurial legacy: Toward a theory of how some family firms nurture transgenerational entrepreneurship. Journal of Business Venturing 30(1): 29-49.

Jaskiewicz, P. and Dyer, W.G. (2017) Addressing the elephant in the room: Disentangling family heterogeneity to advance family business research. Family Business Review 30(2): 111-118.

Kellermanns, F. W., Eddleston, K. A., Sarathy, R., and Murphy, F. (2012) Innovativeness in family firms: A family influence perspective. Small Business Economics 38(1): 85-101.

König, A., Kammerlander, N. and Enders, A. (2013) The family innovator's dilemma: How family influence affects the adoption of discontinuous technologies by incumbent firms. Academy of Management Review 38(3): 418-441.

Kraiczy, N. (2013) Innovations in small and medium-sized family firms: an analysis of innovation related top management team behaviors and family firm-specific characteristics. Springer Science and business media.

La Porta, R., Lopez-de-Silanes, F. and Shleifer, A. (1999) Corporate ownership around the world. The Journal of Finance 54(2): 471-517.

Le Breton-Miller, I., and Miller, D. (2011) Commentary: Family firms and the advantage of multitemporality. Entrepreneurship Theory and Practice 35(6): 1171-1177.

Lettl, C., Herstatt, C. and Gemuenden, H.G. (2006) Users' contributions to radical innovation: evidence from four cases in the field of medical equipment technology. $R \& D$ Management 36(3): 251-272.

Llach, J. and Nordqvist, M. (2010) Innovation in family and non-family businesses: A resource perspective. International Journal of Entrepreneurial Venturing 2(3-4): 381-399.

Lumpkin, G.T. and Brigham, K.H. (2011) Long-term orientation and intertemporal choice in family firms. Entrepreneurship Theory and Practice 35(6): 1149-1169.

Matzler, K., Veider, V., Hautz, J. and Stadler, C. (2015) The impact of family ownership, management, and governance on innovation. Journal of Product Innovation Management 32(3): 319-333.

McElwee, G. (2006) Farmers as entrepreneurs: developing competitive skills. Journal of developmental entrepreneurship 11(03): 187-206.

Memili, E. and Dibrell, C. (2019) Heterogeneity among family firms, London: Palgrave MacMillan. 
Miller, D., and Le Breton-Miller, I. (2005) Managing for the long run: Lessons in competitive advantage from great family businesses. Harvard Business Press.

Miller, D., Wright, M., Breton-Miller, I.L. and Scholes, L. (2015) Resources and innovation in family businesses: The Janus-face of socioemotional preferences. California Management Review 58(1): 20-40.

Miniaoui, H., and Schilirò, D. (2016) Innovation and Entrepreneurship for the growth and diversification of the GCC Economies. Munich Personal RePEc Archive (MPRA Paper No. 71898). Available at: https://mpra.ub.unimuenchen.de/71898/1/MPRA_paper_71898.pdf (accessed 5 April 2020).

Mitchell, J. R., Hart, T. A., Valcea, S., and Townsend, D. M. (2009) Becoming the boss: Discretion and postsuccession success in family firms. Entrepreneurship Theory and Practice 33(6): 1201-1218.

Naldi, L., Cennamo, C., Corbetta, G. and Gomez-Mejia, L. (2013) Preserving socioemotional wealth in family firms: Asset or liability? The moderating role of business context. Entrepreneurship Theory and Practice 37(6): 1341-1360.

Naudé, W. (2010) Entrepreneurship, developing countries, and development economics: new approaches and insights. Small business economics 34(1); 1.

Pratt, M. (2009) For the Lack of a Boilerplate: Tips on Writing up (And Reviewing) Qualitative Research. Academy of Management Journal 52(5): 856-862.

Richards, T.J., and Richards, L. (1994) Using computers in qualitative research. In: Denzin, Y.K., Lincoln, Y.S. (Eds.), Handbook of Qualitative Research. Sage, Thousand Oaks: 445-462.

Roessl, D., Fink, M., and Kraus, S. (2010). Are family firms fit for innovation? Towards an agenda for empirical research. International Journal of Entrepreneurial Venturing 2(34): 366-380.

Rondi, E., De Massis, A., and Kotlar, J. (2018) Unlocking innovation potential: A typology of family business innovation postures and the critical role of the family system. Journal of Family Business Strategy. https://doi.org/10.1016/j.jfbs.2017.12.001

Salvato, C. (2004) Predictors of entrepreneurship in family firms. The Journal of Private Equity 7(3): 68-76.

Schulze, W.S. and Gedajlovic, E.R. (2010) Whither family business?. Journal of Management Studies 47(2): 191-204.

Sciascia, S., Nordqvist, M., Mazzola, P. and De Massis, A. (2015) Family ownership and R\&D intensity in small-and medium-sized firms. Journal of Product Innovation Management 32(3): 349-360.

Sharma, P., Chrisman, J. J., and Chua, J. H. (2003) Succession planning as planned behavior: Some empirical results. Family Business Review 16(1): 1-15.

Suess-Reyes, J., and Fuetsch, E. (2016). The future of family farming: A literature review on innovative, sustainable and succession-oriented strategies. Journal of rural studies 47:117-140.

Uhlaner, L.M., Kellermanns, F.W., Eddleston, K.A. and Hoy, F. (2012) The entrepreneuring family: A new paradigm for family business research. Small Business Economics 38: $1-11$. 
Urbinati, A., Franzo, S., De Massis, A., and Frattini, F. (2017) Innovation in family firms: A review of prior studies and a framework for future research. In A. Brem and E. Viardot (Eds.), Revolution of Innovation Management, Vol. 2 (213-246). London: Palgrave Macmillan.

Utterback, J.M. and Abernathy, W.J. (1975) A dynamic model of process and product innovation. Omega 3(6): 639-656.

Vandemaele, S., and Vancauteren, M. (2015) Nonfinancial goals, governance, and dividend payout in private family firms. Journal of Small Business Management 53(1): 166-182.

Weismeier-Sammer, D., Frank, H., and von Schlippe, A. (2013) Untangling 'Familiness' A Literature Review and Directions for Future Research. The International Journal of Entrepreneurship and Innovation 14(3): 165-177.

Weismeier-Sammer, D., and Hatak, I. R. (2014) Succession in the family business: challenges for successors from an entrepreneurial perspective. The International Journal of Entrepreneurship and Innovation 15(4): 279-284.

Welter, F. (2011). Contextualizing entrepreneurship-conceptual challenges and ways forward. Entrepreneurship theory and Practice 35(1): 165-184.

Wiklund, J. and Shepherd, D. (2005) Entrepreneurial orientation and small business performance: a configurational approach. Journal of Business Venturing 20(1): 71-91.

Wright, M., Chrisman, J., Chua, J.H. and Steier, L., (2014) Family enterprise and context. Entrepreneurship Theory and Practice 38(6): 1247-1260.

Xi, J. M., Kraus, S., Filser, M., \& Kellermanns, F. W. (2015). Mapping the field of family business research: past trends and future directions. International Entrepreneurship and Management Journal 11(1): 113-132.

Yin, R.K. (2015) Qualitative Research from Start to Finish. Guilford Publications.

Zahra, S. A. (1996) Governance, ownership, and corporate entrepreneurship: The moderating impact of industry technological opportunities. Academy of management journal 39(6): 1713-1735.

Zahra, S.A., (2005) Entrepreneurial risk taking in family firms. Family Business Review 18(1): 23-40.

Zahra, S. A., and Wright, M. (2011) Entrepreneurship's next act. Academy of Management Perspectives, 25(4): 67-83.

Zohri, A.N.A. and Etnan, M.M. (2000) Ethanol production from dates in Saudi Arabia on industrial scale. Mycobiology 28(2): 76-81. 
Table 1: Semi- Structured Interview Schedule

\begin{tabular}{|l|l|}
\hline Interviewee background & $\begin{array}{l}\text { Age, education, current position, years of experience in the } \\
\text { family business, years of experience outside the family } \\
\text { business }\end{array}$ \\
\hline Firm background & $\begin{array}{l}\text { year of establishment, main product/service, number of } \\
\text { employees, other activities }\end{array}$ \\
\hline Family Background & $\begin{array}{l}\text { family structure, branches, how many family members } \\
\text { working in the business, what are their positions/ } \\
\text { responsibilities }\end{array}$ \\
\hline Innovation & $\begin{array}{l}\text { self-evaluation of current and future innovation (input/ } \\
\text { process/ output) (product, process, service, radical, and } \\
\text { incremental innovations), factor enhancing innovation in the } \\
\text { firm, sources of innovation (firm tradition/ territorial tradition/ } \\
\text { new practices), role of family in innovation (supporting } \\
\text { /hindering). }\end{array}$ \\
\hline $\begin{array}{l}\text { Governance } \\
\text { Ability as Discretion) }\end{array}$ & $\begin{array}{l}\text { ownership structure/authority/ management/ monitoring and } \\
\text { incentive system/ BOD effectiveness. }\end{array}$ \\
\hline $\begin{array}{l}\text { Family Ability } \\
\text { Resources }\end{array}$ & $\begin{array}{l}\text { Important resources for innovation (social, human, financial, } \\
\text { reputational, familiness), availability of resource, challenges in } \\
\text { sourcing/employing resources. }\end{array}$ \\
\hline $\begin{array}{l}\text { Family Willingness to } \\
\text { Innovate }\end{array}$ & $\begin{array}{l}\text { family business goal (financial/ non-financial), goal changes } \\
\text { over time, family first or business first. }\end{array}$ \\
\hline
\end{tabular}


Table 2: Cases Overview

\begin{tabular}{|c|c|c|c|c|c|c|c|c|c|c|c|c|}
\hline Case & Name & Firm History & $\begin{array}{c}\text { Business } \\
\text { Age }\end{array}$ & $\begin{array}{c}\text { No. of } \\
\text { Employees }\end{array}$ & $\begin{array}{c}\text { Family } \\
\text { Ownership }\end{array}$ & $\begin{array}{l}\text { Number } \\
\text { of family } \\
\text { member } \\
\text { ownership }\end{array}$ & $\begin{array}{c}\text { Generation } \\
\text { working in } \\
\text { the } \\
\text { business }\end{array}$ & $\begin{array}{c}\begin{array}{c}\text { Number } \\
\text { of } \\
\text { family } \\
\text { working } \\
\text { in the } \\
\text { business }\end{array} \\
\end{array}$ & $\begin{array}{l}\text { Family } \\
\text { Member } \\
\text { Position }\end{array}$ & Age & Generation & Relationship \\
\hline \multirow{2}{*}{1} & \multirow{2}{*}{ Barhi } & \multirow{2}{*}{$\begin{array}{l}\text { The founder established it as a } \\
\text { sole proprietorship; he died } 4 \\
\text { years later and the firm has since } \\
\text { been transformed to partnership } \\
\text { between siblings. }\end{array}$} & \multirow{2}{*}{35} & \multirow{2}{*}{150} & \multirow{2}{*}{$100 \%$} & \multirow{2}{*}{$\begin{array}{c}8 \\
\text { (Siblings) }\end{array}$} & \multirow{2}{*}{$2^{\text {nd }}$} & \multirow{2}{*}{2} & Consultant & 47 & $2^{\text {nd }}$ & Brother \\
\hline & & & & & & & & & CEO & 31 & $2^{\text {nd }}$ & Brother \\
\hline \multirow{2}{*}{2} & \multirow{2}{*}{ Sukkari } & \multirow{2}{*}{$\begin{array}{l}\text { After the founder died, one of his } \\
\text { sons took over the business and } \\
\text { restructured it as a brand. }\end{array}$} & \multirow{2}{*}{50} & \multirow{2}{*}{500} & \multirow{2}{*}{$100 \%$} & \multirow{2}{*}{1 (Father) } & \multirow{2}{*}{$2^{\text {nd }} \& 3^{\text {rd }}$} & \multirow{2}{*}{2} & CEO & 51 & $2^{\text {nd }}$ & father \\
\hline & & & & & & & & & $\begin{array}{c}\text { Department } \\
\text { Manager }\end{array}$ & 25 & $3^{\text {rd }}$ & Son \\
\hline \multirow[b]{2}{*}{3} & \multirow[b]{2}{*}{ Sultana } & \multirow{2}{*}{$\begin{array}{l}\text { The founder started the business } \\
\text { as a hobby and as a sole } \\
\text { proprietorship, then added his } \\
\text { brothers to create a partnership. } \\
\text { He now supervises remotely and } \\
\text { has handed over daily operations } \\
\text { to his sons and nephews who have } \\
\text { diversified into other more } \\
\text { profitable sectors. }\end{array}$} & \multirow[b]{2}{*}{37} & \multirow[b]{2}{*}{250} & \multirow[b]{2}{*}{$100 \%$} & \multirow[b]{2}{*}{$\begin{array}{c}3 \\
\text { (Brothers) }\end{array}$} & \multirow[b]{2}{*}{$1^{\text {st }} \& 2^{\text {nd }}$} & \multirow[b]{2}{*}{4} & $\begin{array}{l}\text { Founder/ } \\
\text { Chairman }\end{array}$ & 78 & $1^{\mathrm{st}}$ & Father \\
\hline & & & & & & & & & $\begin{array}{c}\text { Department } \\
\text { Manager }\end{array}$ & 34 & $2^{\text {nd }}$ & Son \\
\hline \multirow[b]{2}{*}{4} & \multirow[b]{2}{*}{ Khalas } & \multirow{2}{*}{$\begin{array}{l}\text { The founder is passionate about } \\
\text { dates. He started a corporation } 15 \\
\text { years ago with over } 100 \\
\text { shareholders but it failed. He } \\
\text { relaunched the business again } \\
\text { with his cousins as partners and } \\
\text { his sons as managers. }\end{array}$} & \multirow[b]{2}{*}{5} & \multirow[b]{2}{*}{30} & \multirow[b]{2}{*}{$75 \%$} & \multirow{2}{*}{$\begin{array}{c}3 \\
\text { (cousins) }\end{array}$} & \multirow[b]{2}{*}{$1^{\text {st }} \& 2^{\text {nd }}$} & \multirow[b]{2}{*}{3} & $\begin{array}{l}\text { Founder/ } \\
\text { Chairman }\end{array}$ & 72 & $1^{\mathrm{st}}$ & Father \\
\hline & & & & & & & & & CEO & 33 & $2^{\text {nd }}$ & Son \\
\hline
\end{tabular}


Table 3: Data Structure

\begin{tabular}{|c|c|c|}
\hline First Order Codes & Second Order Codes & $\begin{array}{l}\text { Aggregate } \\
\text { Theoretical } \\
\text { Dimensions }\end{array}$ \\
\hline $\begin{array}{l}\text { Statements about: } \\
\text { importance of dates (A, B); } \\
\text { national food source (A, B); } \\
\text { nutrition (A); dates as a fruit } \\
\text { (A); patriotism (A); passion } \\
\text { (A, B); social relationship } \\
\text { (A, B); innovation source (A, } \\
\text { B). }\end{array}$ & $\begin{array}{l}\text { Tradition } \\
\text { Culture }\end{array}$ & $\begin{array}{l}\text { Innovation Through } \\
\text { Tradition }\end{array}$ \\
\hline $\begin{array}{l}\text { Statements about: corporate } \\
\text { governance (A); Board of } \\
\text { directors, decision making, } \\
\text { financial resources (A); } \\
\text { human resources (A); know } \\
\text { how (A); family relationship } \\
\text { (A); meaning of business } \\
\text { (A); reputation (A); financial } \\
\text { goals (A); non-financial } \\
\text { goals (A,B); generational } \\
\text { gap (A); challenges; } \\
\text { entrepreneurship (A); } \\
\text { national } \\
\text { exporting (A, B). }\end{array}$ & $\begin{array}{l}\text { Ability as discretion } \\
\text { Ability as resources } \\
\text { Willingness economically } \\
\text { Willingness non-economically }\end{array}$ & Innovation Posture \\
\hline
\end{tabular}

'A' evidence from interviews; ' $B$ ' evidence from archival types. 
Table 4: Findings

\begin{tabular}{|c|c|c|c|c|c|c|c|}
\hline \multirow{3}{*}{$\begin{array}{c}\text { Cas } \\
\text { e }\end{array}$} & \multirow[b]{3}{*}{ Name } & \multirow{3}{*}{$\begin{array}{c}\text { Founder } \\
\text { Phase }\end{array}$} & \multicolumn{4}{|c|}{ Next Generation Phase } & \multirow{3}{*}{$\begin{array}{c}\text { Innovatio } \\
\text { n } \\
\text { Posture }\end{array}$} \\
\hline & & & \multicolumn{2}{|c|}{ Ability } & \multicolumn{2}{|c|}{ Willingness } & \\
\hline & & & $\begin{array}{c}\text { Discretio } \\
n\end{array}$ & $\begin{array}{c}\text { Resource } \\
S\end{array}$ & $\begin{array}{c}\text { Economi } \\
c\end{array}$ & $\begin{array}{c}\text { Non- } \\
\text { economi } \\
c\end{array}$ & \\
\hline 1 & Barhi & \multirow{2}{*}{$\begin{array}{c}\text { Innovativ } \\
\mathrm{e}\end{array}$} & $X$ & $X$ & $\checkmark$ & $\checkmark$ & \multirow{2}{*}{ Lagging } \\
\hline 3 & Sultana & & $\checkmark$ & $\checkmark$ & $\mathrm{X}$ & $\checkmark$ & \\
\hline 2 & $\begin{array}{c}\text { Sukkar } \\
\mathbf{i}\end{array}$ & \multirow{2}{*}{$\begin{array}{c}\text { Not } \\
\text { innovative }\end{array}$} & $\checkmark$ & $\checkmark$ & $\checkmark$ & $\checkmark$ & \multirow{2}{*}{ Reviving } \\
\hline 4 & Khalas & & $\checkmark$ & $\checkmark$ & $\checkmark$ & $\checkmark$ & \\
\hline
\end{tabular}

